\title{
Role model: Claire Lemer
}

\author{
Claire Lemer, a consultant paediatrician at the Evelina London Children's Hospital, tells Adrian \\ O'Dowd how her experience as a patient has helped improve her as a doctor
}

\section{Adrian O'Dowd}

London, UK

Claire Lemer is definitely in the right job and oozes enthusiasm for her work. She qualified as a doctor in 2000 and her current role combines clinical work with service transformation.

The latter involves internal hospital improvements and heading service transformation for the Children and Young People's Health Partnership —an initiative to improve everyday healthcare services for children in the London boroughs of Lambeth and Southwark.

Lemer's work was put on hold in December of last year, however, when she was knocked down by a car while crossing a road, sustaining multiple broken bones.

"I've spent the past five months recovering from that," she says. "It's been an unexpected sabbatical. I spent two weeks in hospital, another eight weeks in a wheelchair because of my fractured pelvis, and then eight weeks doing physio. I am hopeful I will go back to work at the beginning of June."

Despite the experience, Lemer remains positive. "I feel lucky to still be here and the care that I received from the NHS has been amazing," she says. "It's no bad thing for a clinician to experience what it's like to be a patient."

She adds, "I have learnt all sorts of things about what matters to people. I will go back to work and be a better doctor for having lived with this."

Upon her return, Lemer will start as clinical director for medicine at the Evelina, giving her the opportunity to do new things but still carry on transformation work.

During her career, Lemer has worked abroad and was a Harkness Fellow in Health Policy in Boston, USA, during 2004 and 2005. She has also coauthored two books on medical management. She spent two and a half years at the Department of Health and the World Health Organization where she worked in public health, quality improvement, and clinical leadership programme development.

"For me, the joy of working or studying abroad is that it gives you a chance to see different systems. It makes you think about the way we do things in the UK and whether we could do things differently, or better," she says.
Lemer has played a part in influencing national policy and is associate national clinical director for children, young people, and transition to adulthood at NHS England.

"I have been lucky to work in policy and be involved in changes that might have national reach, but often the real satisfaction comes from that one-to-one connection with a patient or a family," she explains.

Encouragement of younger colleagues' development is something Lemer is passionate about, investing time to provide them with the knowledge, skills, opportunities, and connections to progress.

"It gives me immense joy to mentor people," she says. "Just now I have two pre-medical school six formers who I have been meeting with, and I have young clinicians who come and see me regularly."

Lemer also spends time outside of work helping to improve her local, regional, and national communities at organisations including the United Synagogue, a primary school board of governors, and several charities.

Lemer was awarded the British Empire Medal in 2014 for services to children's health - something she is typically humble about. "It was totally unexpected, overwhelming, and wonderful. You also get to meet and hear what the other awardees have done."

To young doctors or medical students, her advice is simple. "If there are things that you want to do, explore them. And never be afraid of asking questions. It's hugely important, as a developing clinician, to spend time thinking about what matters and excites you-and then pursue it with bravery."

\section{Nominated by Miriam Fine-Goulden}

"Claire has many outstanding qualities which make her an incredible role model. She is highly accomplished, yet all her achievements are driven by her desire to do a tremendous job for the people on behalf of whom she is working, rather than to further her own career or fulfil personal ambitions.

"She is hugely impressive, yet immensely humble. She is never self promoting and doesn't regard herself as exceptional."

Miriam Fine-Goulden is a clinical fellow at NHS England 